\title{
Postfeminims and Femvertising Issues on Mountaineering
}

\author{
Ikma Citra Ranteallo \\ Graduate Student of Rural Sociology \\ Institut Pertanian Bogor \\ Bogor, Indonesia \\ ikmacitra@outlook.com
}

\author{
Imanuella Romaputri Andilolo \\ Department of Management \\ Universitas Mataram \\ Mataram, Indonesia \\ Imanuella.andilolo@gmail.com
}

\begin{abstract}
Feminist ideas deal with women struggle and fight for gender equality. Post-feminism has gone beyond that. This movement idealizes women living in individualistic ways based on liberal agenda. Some Nepali women organized their visions on the base of education, empowerment, and environment, and set off to conquer the highest peaks in the world. Their experiences on the highest peaks are part of their life as highlanders and their admiration for the outdoors has bring different perspective on women and outdoor brands that supported them. We argue that the use of femvertising on mountaineering gears as marketing strategies has been arising to celebrate and empower women and girls. Consumer culture needs a heroine who is wearing outdoor gears on ads.
\end{abstract}

Keyword: Postfeminism, femvertising, women, mountaineering, outdoor, ads

\section{INTRODUCTION}

Postfeminist discourse has been adopted by neoliberalism, economic, social and policy reform on a global scale, global media audience [1]. It has been defined as a depoliticization of feminist goals [2]. Showed [3] made three groups of people who belong to the term postfeminism: firstly, those who argue that feminism rep-resents as a social movement and the statement it implicitly makes about the nature and status of women are offensive and inappropriate in the current era; secondly, there are others who draw on critiques generated by the second wave of feminist praxis, especially critiques of essentialism launched by lesbian and women-of-color feminists; and finally, group indicates work inspired by poststructuralist, postmodern, or multicultural theory, specifically in relation to the critique of the stable, unitary political subject that was presumed to be the necessary locus for feminist agency and politics.

We argue that the rise of postfeminism have encouraged the use of femvertising as marketing strategies to celebrate and empower women and girls. Sports that have previously have been dominated largely by men are now being experienced and enjoyed by women as well. This paper looks specifically at mountaineering and how producers of mountaineering products have used femvertising in garnering attention to their female wears and gears.
Pasang Lhamu Sherpa Akita was the first Nepali woman to summit Everest and one of the first Nepali mountaineers to garner financial sponsorship for her Everest expedition. She was named the 2016 Adventurers of the Year for The Mountaineer, organized by National Geographic [4]. Consumer culture needs a heroine who is wearing outdoor gears on ads. Sherpa Adventure Gear and Black Diamond are the two brands that were mentioned by Pasang on The Outdoor Journal's interview [5]. The use of femvert could be identified through those brands, especially in their special outdoor gears for women.

\section{RESEARCH METODOLOGY}

The research conducted by analytical qualitative method on postfeminism values and femverts contents of mountaineering gears. This is the preliminary study to overview how the outdoor gears create femverts to celebrate gender equality and make a profits.

There are three brands that had been analyzed: Sherpa Adventure Gear and Black Diamond. Two detail reviews on outdoor gears could be found on $<$ http://www.outdoorgearlab.com/> [6] and <www.whittakermountaineering.com>[7], included: Overview the product, ratings, price vs. value chart, buying advice, and how we test. The reviews on mountaineering gears could be released by the consumers or commercial mountainners.

\section{RESULTS AND DISCUSSION}

\section{A. Femvertisting}

Studies on feminism and advertisement (ads) have created the term "femvertising" (fem-vertising; femverts) [8], [9], [10] [11], and [12]. Femverts is provoking feminist values and female empowerment to encourage brand activism, so that consumers voluntarily participating in championing the social cause together with the brand by engaging with the content online.

The term "femvertising" has been widely used by the media as:

1. ...ads that celebrate women and girls rather than objectify them have become wildly popular. [13]; 
2. ...over $52 \%$ of women bought a product because they like how the company's marketing portrayed women, and over half of the women surveyed said they liked the adverts because they champion gender equality. [14];

3. ...brands started to make impact by numerous female-oriented campaigns, most impressively, denying the notion that a woman's worth correlates to her physical appearance. [15];

4. In 2015, SheKnows Media launched the \#Femvertising Awards to honor brands that are challenging gender norms by building stereotype-busting, pro-female messages and images into ads that target women. The winners are: Dove and Twitter (Social Impact Winner); HelloFlo (Humor Winner); Always (Next Gen Winner); RAM Trucks (Inspiration Winner); Sport England (Hatch Kid's Choice Winner); Sayfty (People's Choice Winner); and L'Oreal (Wildfire Winner) [16]

Some keywords refer to femverts are: ads to celebrate women and girls; marketing portrayed women; champion gender equality; female-oriented campaigns; and pro-female messages and images on ads. Kitty Calhoun "...was paid to test products for a mountaineering gear and clothing manufacturer in the United States (and continues to do so as an 'alpine ambassador' for the company, Patagonia).” [17].

\section{B. Mountaineering}

Mountaineering has been packed in holidays and encouraged by advances in equipment and technology. Many references on mountaineering co modification could be found on movies, novels, guide pocket books, and mountaineering websites. They are supplying knowledge about the experiences and personal emotional journeys of recreational adventurers [18]. Mountaineering has been typically seen as a masculine sport, with only limited interest in women.

A mountaineer's enduring personality traits had been identified by basic emotions, joy and fear, and examined the roles of those basic emotions in satisfaction formation in the context of mountaineering experiences. Mountaineering in the classic sense (climbing and walking) has been re-invented and new forms of mountain-based adventure activities such as abseiling or repelling, multi-day trekking, sports climbing, and mountain-biking have emerged [19].

\footnotetext{
“...Studies in social sciences argue a different perspective on risk in adventure sports by trying to better understand why people participate in these activities..." [20].
}

"...differences in movement culture and exercise habits, working conditions and travel behaviour, landscape and climate as well as political and social conditions influence experiences and physical activity in natural environments [21].

“...Nature offers real or apparent risk, a novel and unfamiliar physical environment separate from the routines of everyday life, unique rules to be followed, esthetic and spiritual qualities, and physical and emotional challenges Participation, therefore, requires specific knowledge, skills, and abilities related to outdoor environment [22].

"...Mountaineering demands active engagement from participants involving such activities as scrambling, rope- work, travelling across glaciers, use of ice axes and crampons, acclimatisation and navigation." [23]

The motives that drive mountaineer have a variety of categories: social engagements, satisfaction, pride, and commercial mountaineering. The latest motive guides hundreds of different commercial mountaineering tour and guiding companies around the world, and most specialize in one articular mountain range, or the ranges of one particular continent. Their services depend on market demand; local climbing conditions; the depth of guiding knowledge in each company; transport, services and infrastructure; and political stability in the countries concerned [25].

\section{Postfeminism}

There is a continuing debate among scholars on the definition of postfeminism. Nevertheless, the history of postfeminism itself is clear. It is a manifestation of feminist movement that for decades has struggled and fight for gender equality. As Scott [26] highlighted Gill's conceptualization of postfeminism: “...postfeminism not as epistemology, era, identity, or movement, but a sensibility that is widely apparent in media products and properties. This sensibility expresses a cultural condition, configuration, or logic operating within contemporary gender ideals and relations but also more broadly applicable...". Postfeminism speaks of the ability of women to make choices without gender boundaries. There is a sense of freedom and independence attached to postfeminism. It certain is not a movement as its predecessor the feminist movement was. Postfeminism has become a way of life for many societies, some without even acknowledging or even understood the struggles to get here. This in itself portrays the struggle in defining postfeminism.

Postfeminism and neoliberalism are in the same notions of individual, the constant surveillance, monitoring, and disciplining of the self, with an emphasis on the resexualization of women's bodies, individualism, empowerment, and choice, as well as consumerism and the commodification of difference [27]. This emphasizes the power marketing strategy has in promoting postfeminism issues through fermvertising.

Women who are doing mountaineering, climbing, or hiking, not only to satisfy needs for closer to nature but also to 
demonstrate women's power and strength in a sport that is mainly considered as masculine sport or activity. An expert female mountaineering, shared her experience on the Everest base camp [28]:

\begin{abstract}
"Our arrival sparked a flurry of gossip and controversy amongst the mountaineers and expedition support people who make up the temporary inhabitants of this otherwise barren landscape, including a number of western doctors and Sherpa and Sherpani mountaineers...The trek into Everest Base Camp is arduous, requiring many days of travel on foot over a number of passes eventually to an altitude of 17,500 feet. Our children were often commended for their strength and fitness, even the baby who rode in a carrier on her father's back all of the way! But Everest Base Camp is a space cordoned off for the serious adult pursuit and pleasureseeking of high-altitude mountaineering. In this vein, many of the women I interviewed at Base Camp encouraged and celebrated my efforts to combine work and family in so adventuresome and masculine a space...".
\end{abstract}

Her multitasking on climbing, taking care of the children, and doing field work break through myths, notions, and history that masculinized adventure-travel could only be done by men. Mountaineering travel as a discourse about men's escape from home, and about motherhood as dominant discourse on 'good mothers' remaining close by their children [29]. She also went on describing another female mountaineering, Lhakpa Sherpa, where her mountaineering experience is "shaped by a social memory linking motherhood and feminine subjectivity in complex ways". Lhakpa Sherpa is a Nepalese woman that has climbed Mount Everest for a record seventh time by a woman.

\section{The Implications of Femverts on Mountaineering Gears}

“...the 'Golden Age' of mountaineering ranged from 1854, when Alfred Wills climbed the Wetterhorn (3,692m), to 1865 when Whymper first stood on the Matterhorn (4,478m) [30]. During this period, men climbed most of the principal summits for the first time. Mrs Hamilton...in the same year Wills climbed the Wetterhorn, became the first British woman to climb Mont Blanc (4,810m). Miss Forman followed her in 1856 and by 1861 women made the ascent on an annual basis. By the mid $1870 \mathrm{~s}$, a woman had stood on most Alpine summits. Women in the mountains had clearly been transgressing notions of moderate exercise for over 40 years prior to $1900 \ldots .$.

The diagnosis of injuries of summer climbing on Fujisan's north face from 1989 to 2008 predetermined categories such as "suitable" gear and the presence of "appropriate" footwear [31].

For commercial adventure tours, the quality of equipment required depends strongly on the market sector at which the tour is pitched. For any trip where participants and their gear will be put severely to the test, top-quality equipment is an essential investment, for insurance as well as practical purposes. For high-volume, low-risk trips where equipment is used repeatedly, the most critical issue is durability. Many companies that offer tours of this type have routine strategies to replace all of their equipment at the end of each season. Often they sell the old gear

second-hand: either to former clients; to guides for private use; or in developing nations especially, to lower-priced operators offering the same activity. [32]

The importance of outdoor gears, sociologically, developed the fashion, while studies on design and marketing also increased the number of indicators. An important tactic for negotiating risk is to select routes which offer challenges that will not escape the control of the climber [33]. Here the routinization of risk perception and practice a disposition of risk is produced.

\begin{tabular}{|c|c|c|c|}
\hline TABLE I. & FEMVERTS & AND MOUNTAINEER & TG GEARS \\
\hline \multirow[b]{2}{*}{ BRAND } & \multicolumn{3}{|c|}{ FEMVERTS AND MOUNTAINEERING GEARS } \\
\hline & $\begin{array}{c}\text { Gears } \\
\text { category }\end{array}$ & Femverts issue(s) & $\begin{array}{c}\text { Heroine } \\
\text { (Ambassador; } \\
\text { Athlete) }\end{array}$ \\
\hline $\begin{array}{l}\text { Sherpa } \\
\text { adventure } \\
\text { gear }\end{array}$ & $\begin{array}{l}\text { Women's: } \\
\\
\text { Sweaters } \\
\text { Insultion } \\
\text { Mid Layer } \\
\text { Tops } \\
\text { Bottoms } \\
\text { Accessories }\end{array}$ & $\begin{array}{l}\text { a small donation is } \\
\text { made to provide } \\
\text { scholarships to } \\
\text { children who grow } \\
\text { up in remote } \\
\text { Himalayan villages } \\
\text { creating jobs for } \\
\text { women Nepal }\end{array}$ & $\begin{array}{l}\text { Pasang Lhamu } \\
\text { Sherpa } \\
\text { Dawa } \\
\text { Yangzom Sherpa } \\
\text { Heather Geluk }\end{array}$ \\
\hline $\begin{array}{l}\text { Black } \\
\text { Diamond }\end{array}$ & $\begin{array}{l}\text { Women's: } \\
\text { Softshell } \\
\text { Jackets } \\
\text { Insulation } \\
\text { Fleece } \\
\text { Hoodies } \\
\text { Tops } \\
\text { Softshell } \\
\text { Pants } \\
\text { Capris } \\
\text { Shorts } \\
\text { Hats } \\
\text { Beanies } \\
\text { Belts } \\
\text { Bras } \\
\text { Shirts }\end{array}$ & $\begin{array}{l}\text { An article "a } \\
\text { question of } \\
\text { determination: the } \\
\text { gender gap" has } \\
\text { been published } 23 \\
\text { December } 2014 \text { on } \\
\text { Black Diamond } \\
\text { website. There are } \\
\text { two photographs } \\
\text { attached of Brigid } \\
\text { Mander, who are } \\
\text { using the products. } \\
\text { "...They funded half } \\
\text { our budget, because } \\
\text { it was the first time } \\
\text { an all-women's team } \\
\text { attempted this } \\
\text { summit. Some well- } \\
\text { known brands gave } \\
\text { us clothing..." }\end{array}$ & $\begin{array}{l}\text { Hazel Findlay } \\
\text { Daila Ojeda } \\
\text { Babsi Zangerl } \\
\text { Many more }\end{array}$ \\
\hline
\end{tabular}

Adapted from brands' websites, October 2016

One of the outdoor gears that produced locally Pasang Lhamu as the ambassador - is Sherpa Adventure Gear, was founded in May 2003 by Tashi Sherpa. Its details based on "...ancient carvings and patterns...tribute to ...heritage and the people and cultures...homeland..." [34]. The brand released \#wearesherpa for engaging the consumers. Table I described how femverts issues elaborated in outdoor brands.

\section{CONCLUSION}

Based on the previous discussion on the role of social capital in support of sustainable development contained in rite Manuba Ba Adat, the conclusions of this paper are:

First, activities rite Manuba Ba Adat can run well because of the full support of the community. This can be seen in public 
participation from the planning (contribute) to the implementation. Social capital is bound owned by the community to make them committed, consistent and responsible for compliance with applicable pamali system.

Second, to maintain activity Manuba Ba Adat, not just rely on social capital owned by the local community but all stakeholders in the district Lamandau should be mutually supportive.

\section{ACKNOWLEDGMENT}

The author would like to thank the Foundation Kotawaringin Antakusuma University, Rector of the Antakusuma University, Lamandau District Government for financial support and Dr. Giri Pamerdi Wiloso, M.Si the criticism and suggestions that have been given.

\section{REFERENCES}

[1] S. Genz, "Third Way/ve. The politics of postfeminism," Feminist Theory, vol. 7(3), pp. 333-353, December 2006.

[2] J. Gwynne, "Japan, postfeminism and the consumption of sexual(ised) schoolgirls in male-authored contemporary manga," Feminist Theory, vol, 14(3), pp. 325-343, December 2013

[3] C.R. Showden, "What's political about the new feminisms?," Frontiers: A Journal of Women Studies, vol. 30(2), pp. 166-198, 2009.

[4] S. Frohlick, "'Who is Lhakpa Sherpa?' circulating subjectivities within the global/local terrain of Himalayan mountaineering," Social \& Cultural Geography, vol. 5(2), pp. 195-212, June 2004

[5] S. Vohra, "Three female climbers from Nepal summit K2," $<$ http://www.outdooriournal.com/in/news-2/three-female-climbers-firstfrom-nepal-to-summit-k2/->, August 2014. Accessed 17 Ocober 2016.

[6] L.D. Jalakas, "The Ambivalence of \#femvertising: exploring the meeting between feminism and advertising through the audience lens," Master Thesis, Msc Media and Communication Lund University, 2016.

[7] Becker-Herby, "The rise of femvertising: authentically reaching female consumers," 2016

[8] A. Abitbol and M. Sternadori, "You act like a girl: an examination of femvertising and consumer perception," Quarterly Review of Business Disciplines, vol. 3(2), pp.117-138, August 2016.

[9] B.E. Efird "Beautiful is as beautiful does: an integrated social marketing campaign to reframe beauty," Master of Thesis Graduate Project Presented to the Faculty of the Communication Division, Pepperdine University, April 2016.

[10] K.B. Marcus Reker, "'Why can't run 'like a girl' also mean win the race?': commodity feminism and participatory branding as forms of selftherapy in the neoliberal advertising space," 2016. Scripps Senior Theses. Paper 759. http://scholarship.claremont.edu/scripps_theses/759.

[11] N. Bahadur, "Femvertising' ads are empowering women — and making money for " brands," $<$ http://www.huffingtonpost.com/2014/10/02/femvertising-advertisingempowering-women_n_5921000.html> Updated 3 October 2014. Accessed 10 October 2016
[12] Anonim, "\#Femvertising: brands build on empowering women," $<$ http://www.popgroup.hu/news/56-femvertising-brands-build-onempowering-women> 5 May 2015. Accessed 10 October 2016.

[13] M. Hui, "What is 'Femvertising'? $<$ http://www.herculture.org/blog/2015/5/1/what-isfemvertising\#.WAlNFuWLTIU $>18$ Mei 2015. Accessed 10 October 2016.

[14] <http://www.sheknowsmedia.com/2015-femvertising-awardsfrequently-asked-questions $>$. Accessed 10 October 2016

[15] S. Frohlick, "'Wanting the Children and Wanting K2': The incommensurability of motherhood and mountaineering in Britain and North America in the late twentieth century," Gender, Place \& Culture, vol.3, no.15, pp. 477-490, 2006.

[16] G. Pomfret, "Personal emotional journeys associated with adventure activities on packaged mountaineering holidays," Tourism Management Perspectives, 4, pp. 145-154, 2012.

[17] R. Faullant, K. Matzler, and T.A. Mooradian, "Personality, basic emotions, and satisfaction: Primary emotions in the mountaineering experience,” Tourism Management, vol. 32, pp. 1423-1430, 2011.

[18] P. Haegeli and U. Pröbstl-Haider (Ed.), "Risk in outdoor recreation and nature based tourism," Journal of Outdoor Recreation and Tourism, vol. 13, pp. 1-90, April 2016

[19] R. Faullant, K. Matzler, and T.A. Mooradian, "Personality, basic emotions, and satisfaction: Primary emotions in the mountaineering experience,” Tourism Management, vol. 32, pp. 1423-1430, 2011.

[20] K.S. Lekies, G. Yost, and J. Rode, "Urban youth's experiences of nature: Implications for outdoor adventure recreation," Journal of Outdoor Recreation and Tourism, vol. 9, pp. 1-10, 2015

[21] G. Pomfret, "Mountaineering adventure tourists: a conceptual framework for research," Tourism Management, vol. 27, pp. 113-123, 2006

[22] J. Goucher and W.C. Horrace, "The value of life: Real risks and safetyrelated productivity in the Himalaya," Labour Economics, vol. 19, pp. 27-32, 2012.

[23] R. Hales, "Mountaineering," In Ralf Buckley (Ed.) Adventure tourism, (pp. 260-285). Oxfordshire: CABI. ISBN: 9781845931223, 2006

[24] D.T. Scott, "The postfeminist user," Feminist Media Studies, vol. 10(4), pp. 457-475, 2010.

[25] M. Meyers, "The war on academic women: reflections on postfeminism in the neoliberal academy," Journal of Communication Inquiry, vol 37(4), pp. 274-283, 2013.

[26] S.E. Frohlick, “'“You brought your baby to base camp?" Families and field sites," The Great Lakes Geographer, vol. 9(1), 2002.

[27] Frohlick, 2006.

[28] C. Roche, "Women climbers 1850-1900: A challenge to male hegemony?," Sport in History, pp. 1-21, 2013.

[29] T.E. Jones, K. Yamamoto, U. Hayashi, and N.R. Jones, "Summer climbing incidents occurring on Fujisan's north face from 1989 to 2008," Wilderness \& Environmental Medicine, 25, pp.378-383, 2014

[30] R. Hales, "Mountaineering," In Ralf Buckley (Ed.) Adventure tourism, (pp. 260-285). Oxfordshire: CABI. ISBN: 9781845931223, 2006.

[31] M. Bunn, "A disposition of risk: Climbing practice, reflexive modernity and the habitus," Journal of Sociology, pp. 1-15, June 2016

[32] 〈https://www.sherpaadventuregear.com/>. Accessed 10 October 2016. 